\title{
Emergence of Dallisgrass as Affected by Soil Water Availability
}

\author{
Patricia S. Cornaglia, ${ }^{1}$ Gustavo E. Schrauf, ${ }^{3}$ Matias Nardi, ${ }^{2}$ \\ and V. Alejandro Deregibus ${ }^{3}$
}

\author{
Authors are ${ }^{1}$ research senior, ${ }^{2}$ assistant research scientist, and ${ }^{3}$ professors, Department of Animal Science, \\ Facultad de Agronomia, Universidad de Buenos Aires, CPA C1417DSE, Buenos Aires, Argentina.
}

\begin{abstract}
Water supply affects seed germination and seedling establishment of shallow-rooted warm-season grasses. This may explain the difficulty of incorporating Dallisgrass (Paspalum dilatatum Poir.) into humid temperate grasslands through interseeding. We studied the effects of water availability on seed germination and seedling growth under controlled conditions to determine which step of the establishment process was most affected. In a laboratory experiment, seeds were germinated at $0,-0.25,-0.5,-0.75$, and $-1 \mathrm{MPa}$ water availability generated with solutions of polyethylene glycol. Although both maximum rate and total germination $(P<0.05)$ significantly decreased with increased water stress, the speed of germination was even more sensitive. In a greenhouse experiment, variations in seedling emergence and morphological characteristics were measured in relation to water availability. Pregerminated and dry seeds were sown in pots that were irrigated at 1-, 2-, 4-, or 7-day intervals. This species showed high sensitivity to water stress during germination and early emergence. High emergence was obtained from the daily irrigation treatment. In all other treatments, where watering frequency was extended, emergence was decreased. Results suggest that rapid germination and early adventitious root growth can be obtained only with reliable availability of water. These conditions, combined with the high temperatures required for breaking seed dormancy, occur infrequently, explaining the difficulty of achieving successful establishment of Dallisgrass. Water availability during seed germination and seedling emergence is a critical factor for survival of this species.
\end{abstract}

\section{Resumen}

El suministro de agua afecta la germinación y el establecimiento de las gramíneas megatérmicas de raíces superficiales. Esto puede explicar la dificultad para incorporar Pasto miel en pastizales templado húmedos por medio de la intersiembra. Se evaluaron los efectos de la disponibilidad hídrica sobre la germinación y el crecimiento de plántulas bajo condiciones controladas para determinar cuál es el paso del proceso de establecimiento que es más afectado. En un experimento de laboratorio se incubaron semillas variando la disponibilidad de agua mediante el uso de soluciones acuosas de Polietilenglicol (PEG 8000) $(0,-0.25,-0.5,-0.75, y-1 \mathrm{MPa})$. La velocidad de germinación fue más sensible que la germinación total al aumento del estrés hídrico, aunque ambas disminuyeron significativamente $(P<0.05)$. En un experimento, realizado en invernáculo, se caracterizó morfológicamente el crecimiento aéreo y radical de plántulas con diferente disponibilidad hídrica. Se sembraron semillas pre-germinadas y secas en macetas sometidas a diferentes frecuencias de riego (cada 1, 2, 4, y 7 días). Esta especie mostró una sensibilidad elevada al estrés hídrico durante la germinación y la emergencia temprana. La mayor emergencia se obtuvo bajo el tratamiento de riego diario. En los otros tratamientos, la emergencia de plántulas disminuyó con la menor frecuencia de riegos. Los resultados sugieren que la germinación rápida y el desarrollo temprano de las raíces adventicias sólo pueden lograrse con una disponibilidad de agua segura. Estas condiciones, combinadas con las temperaturas elevadas requeridas para romper la dormición de las semillas ocurren con baja frecuencia, y explicarían la dificultad para lograr el establecimiento exitoso de Pasto miel. La disponibilidad de humedad durante la germinación de las semillas y la emergencia de las plántulas es un factor crítico para la sobrevivencia de esta especie.

Key Words: Paspalum dilatatum Poir., seed germination, seedling morphology, water stress

\section{INTRODUCTION}

Soil moisture during seed germination and seedling emergence are highly determinant of the successful establishment of plants,

The investigations were supported by the National Council for Scientific and Technical Research (CONICET).

Correspondence: Patricia S. Cornaglia, Department of Animal Science, Facultad de Agronomía, Universidad de Buenos Aires, CPA C1417DSE Buenos Aires, Argentina. Email: cornagli@mail.agro.uba.ar

Manuscript received 12 June 2003; manuscript accepted 12 September 2004. particularly in the case of warm-season perennial grasses. This is important not only under arid or semiarid conditions but also in humid climates, where droughts of variable intensity and duration also occur.

Dallisgrass (Paspalum dilatatum Poir.) is a warm-season grass native to eastern Argentina, Uruguay, and southern Brazil that is well known for its forage quality and its high preference by cattle (Lemcoff et al. 1978). The inclusion of this species in temperate pastures increases summer productivity and digestible dry matter production in heavy or clayey soils (Acosta et al. 1994). It is more common in humid and very humid sites 
Table 1. Average soil water content (MPa) near the soil surface $(5 \mathrm{~mm}$ seed zone) (shallow) and in seminal root zone $(20 \mathrm{~mm})$ (depth).

\begin{tabular}{clc}
\hline Treatment & Shallow & Depth (MPa) \\
\hline W2 & -0.0039 & -0.012 \\
W4 & -48 & -1.62 \\
W7 & -60 & -1.99 \\
\hline
\end{tabular}

(Burkart et al. 1990). This pattern can be explained by its tolerance of flooding (Loreti et al. 1994; Rubio et al. 1995; Loreti and Oesterheld 1996; Grimoldi 2000). Its low frequency in environments where water stress occurs might be explained by difficulties in seedling establishment.

Many years ago, several authors recognized the difficulty of establishing this species. They attributed it to low seed quality and slow emergence (Burton 1942; Owen 1951). Several attempts to improve establishment of this species were unsuccessful, except when seed presowing treatments or residue cover were used (Schrauf et al. 1995a; Rossi et al. 1998). However, there were discrepancies in the results of those experiments. One possible explanation for the repeated failures in seedling establishment when presowing techniques were applied could be the death of seedlings after emergence due to dehydration. Slow seed germination and seedling emergence extend the period of susceptibility. Therefore, successful establishment is less likely to occur under variable water conditions. Slow seedling growth after emergence is attributed to late development of the root system (Hyder et al. 1971; Frasier et al. 1984; Hsu and Nelson 1986). The relationships between soil water potential, seed germination, and initial seedling growth of Dallisgrass have not been studied in detail.

It is necessary to determine thresholds of soil water stress tolerance to seed germination and seedling emergence and growth before this species can be successfully introduced in pastures and grasslands. Furthermore, a detailed description of seedling morphological development could improve our understanding of the establishment process of this species. We conducted experiments under laboratory and greenhouse conditions to determine the effect of soil water content on seed germination and initial seedling growth of Dallisgrass. In the laboratory, we determined the water potential threshold for Dallisgrass seed germination by using osmotic solutions. In a greenhouse experiment, we investigated seedling emergence and morphology in relation to soil water availability.

\section{MATERIAL AND METHODS}

The term seeds is used herein in the generic sense and includes the lemma, palea, and caryopsis of Dallisgrass. A seed lot commercially produced in Australia was used. It was 1 year old. Seeds were maintained air dry at room temperature until used in experiments.

\section{Experiment 1: Seed Germination (as Affected by Water Stress)}

In order to determine a water potential threshold for Dallisgrass seed germination, water stress was generated using aqueous solutions of polyethylene glycol (PEG 8000): 0, 13.5, 20,25 , and $29 \mathrm{Gr} / 100 \mathrm{ml}$ of distilled water to obtain $0,-0.25$, $-0.5,-0.75$, and $-1 \mathrm{MPa}$ water potential (Parmar and Moore 1966; Hardegree and Emmerich 1994). The water potential of solutions was measured in a Wescor vapor pressure osmometer (C-52 psychrometric chambers attached to a HR-33T Dew Point Microvoltmeter [Wescor Inc, Logan, UT]) after calibration with standard $\mathrm{KCl}$ solutions. Four replications of 50 seeds each were placed in Petri dishes containing filter paper and the solution corresponding to each treatment. Dishes were sealed with Parafilm to prevent water evaporation. Each 7 days, seeds were changed to Petri dishes with the new solution. Germination conditions were $20^{\circ} \mathrm{C} / 35^{\circ} \mathrm{C}$ (16 hours $/ 8$ hours with light). Red light $\left(24 \mu \mathrm{mol} / \mathrm{m}^{2} \mathrm{seg} ; 700 \mathrm{~nm}\right)$ was provided for $4 \mathrm{red}$ fluorescent tubes (Phillips TL 15/40) (Schrauf et al. 1995a). Daily germination was recorded for 28 days using protrusion of the radicle as the criterion for germination. Viability of ungerminated seeds was tested using tetrazolium chloride.

\section{Experiment 2: Seedling Emergence and Morphology Under Different Water Regimes}

The effect of watering frequency on seedling emergence and initial seedling growth was studied in the greenhouse under controlled temperatures $\left(25 \pm 5^{\circ} \mathrm{C}\right)$. Natural light was not limiting to seedling growth and was similar to outdoor levels. Seeds were planted in rectangular plastic pots $(10 \times 20 \mathrm{~cm} \times 5$ $\mathrm{cm}$ tall), with 4 holes in the bottom. To ensure that seeds other than the ones we planted were not present, we used a sieved mixture of sand and soil (50/50). Thirty seeds per pot were planted at a depth of $5 \mathrm{~mm}$. The experimental design was a randomized complete block with 8 replications. Both dry (not pretreatment) and pregerminated $\left(48\right.$ hours at $20-35^{\circ} \mathrm{C}$ on moist blotters) seeds were seeded to separate the effects of water stress on seed germination and seedling emergence.

Watering regimes were selected to simulate the wide range of soil water conditions that may occur during the season in periods of emergence. Four treatments were applied: continuous field capacity and 3 watering frequencies, every 2, 4, and 7 days (treatments were identified as FC, W2, W4, and W7, respectively). For all treatments, subirrigation was provided during a few minutes until the soil surface appeared humid. Besides watering frequency, the FC treatment was different from W2, W4, and W7 in another respect: while these were allowed to drain freely after irrigation, FC pots were located inside other pots without holes. Soil water content at the level of the seed $(0.5 \mathrm{~cm})$ and seminal roots $(2 \mathrm{~cm})$ was determined in 6 additional unseeded pots by using the filter-paper method (see Greacen et al. 1989) (Table 1).

Seedling emergence and leaf appearance were recorded daily. Fifteen seedlings from each treatment $(2$ of each repetition) were harvested after 15 days of emergence. The soil was washed from seedling roots and they were protected from desiccation. The following morphologic parameters were measured: number of emerged leaves, total height $(\mathrm{cm})$, length of seminal root, and number and length of adventitious roots. Aboveground and belowground biomass were determined by oven drying at $45^{\circ} \mathrm{C}$ for 48 hours. Biomass partitioning and shoot (aboveground) height/root length ratio were calculated. In order to estimate seed survival and germinability of un- 
A.

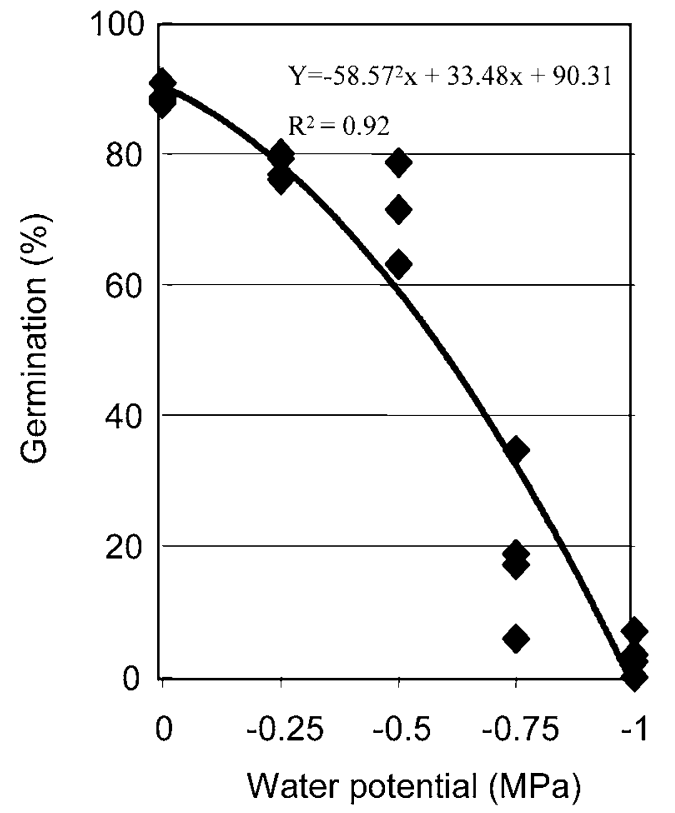

B.

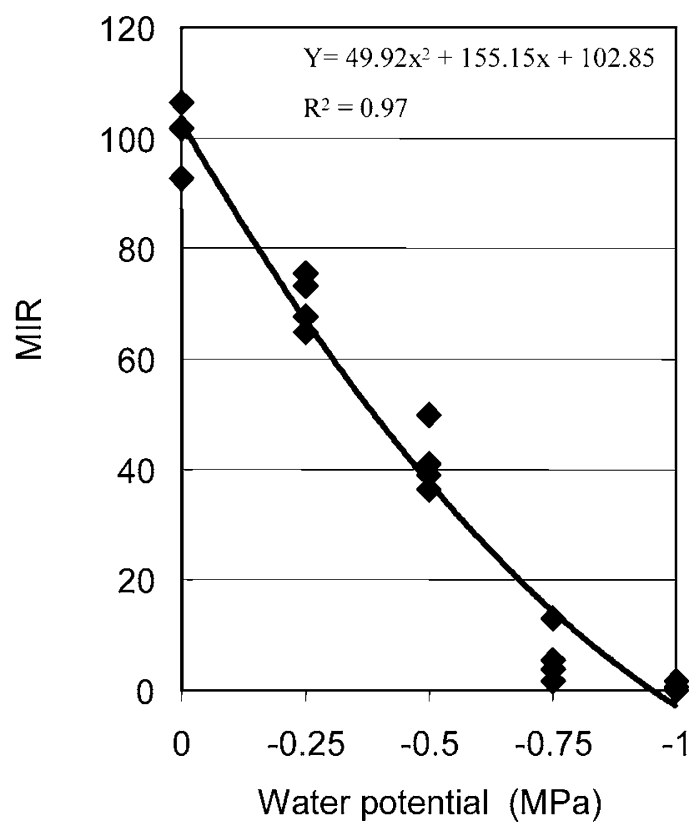

Figure 1. A, Total germination (percent). B, Initial speed germination (MIR Index) as a function of water potential (MPa). ${ }^{*}$ MIR indicates Maguire Index Rate is an estimator of initial germination.

germinated seeds, at the end of the experiment (4 weeks), all pots were irrigated daily for 30 days and all germinated seeds were counted.

\section{Statistical Analyses}

Quadratic regression equations were calculated to relate initial and total germination to water potential. The speed of germination was estimated using the Maguire Index Rate (Maguire 1962), calculated as the sum of the percentage of seeds germinating on each day divided by the number of days since the germination test began. Total germination was determined at the end of the experiment.

Randomized complete block analysis of variance was performed on seedling emergence and on seedling morphologic and allometric parameters. Scheffe's test was used to compare treatment means. An emergence index (Brar et al. 1992) was calculated using the following formula: $I_{e}=\sum e_{i} / d_{i}$, where $e_{i}=$ the cumulative number of seedlings emerged on day $i$ and $d_{i}=$ number of days from planting to day $i$.

\section{RESULTS}

\section{Experiment 1: Seed Germination}

Germination decreased with increasing water stress. Initial $\left(r^{2}=0.97\right)$ and total $\left(r^{2}=0.92\right)$ germination of Dallisgrass were affected by reductions in water availability (Figs. $1 \mathrm{~A}$ and 1B). At $-0.75 \mathrm{MPa}$, germination was decreased by $22 \%$ and rate of germination was reduced by 5.96. At $-1 \mathrm{MPa}$, seeds were swollen and radicle protrusion did not occur. Time to $50 \%$ germination of control seeds was less than 4 days, whereas at $-0.75 \mathrm{MPa}$, it exceeded 10 days. Water stress treatments did not affect viability because seed mortality was $10.6 \%(\mathrm{SE}= \pm 2.6 \%)$ for all treatments $(P=0.15)$.

\section{Experiment 2: Seedling Emergence and Morphology Under Different Water Regimes}

Seedling Emergence and Survival. Seedling emergence from pregerminated and dry seeds were significantly improved

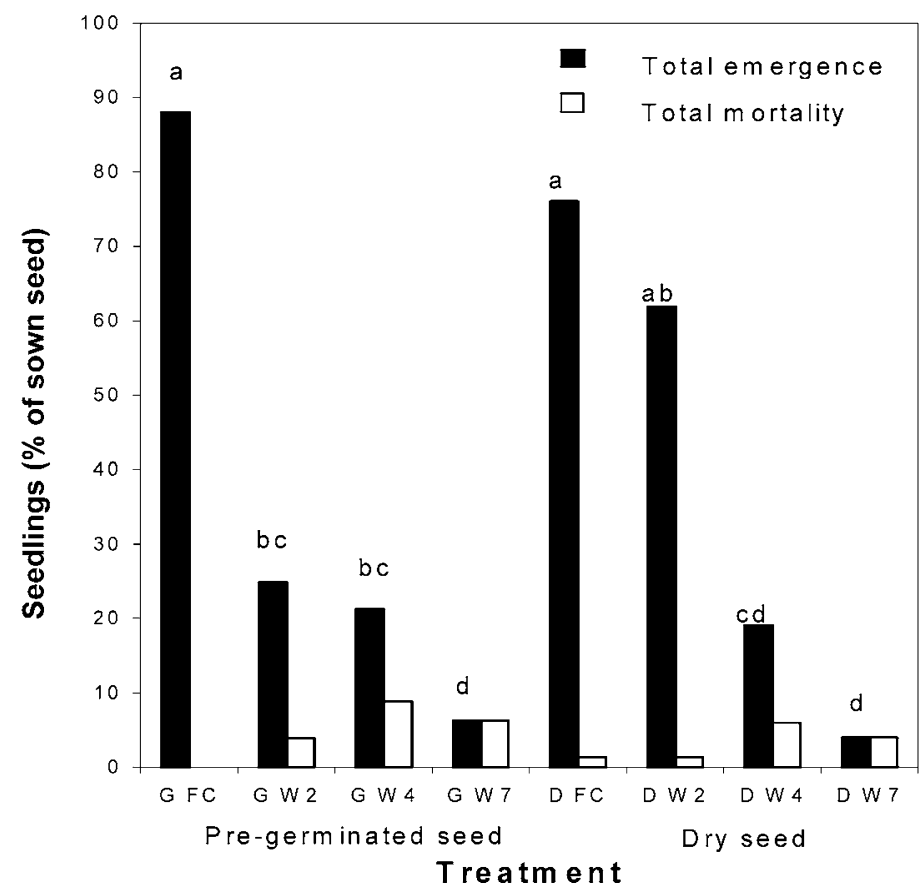

Figure 2. Total emergence and mortality of emerged seedlings as percent of sown seeds of Dallisgrass as a percent of pregerminated and dry (not treated) sown seed and under 4 irrigation frequencies: Field capacity (FC), or irrigated every 2 (W2), 4 (W4), or 7 days (W7). Different letters indicate significant differences $(P \leq 0.05)$. 

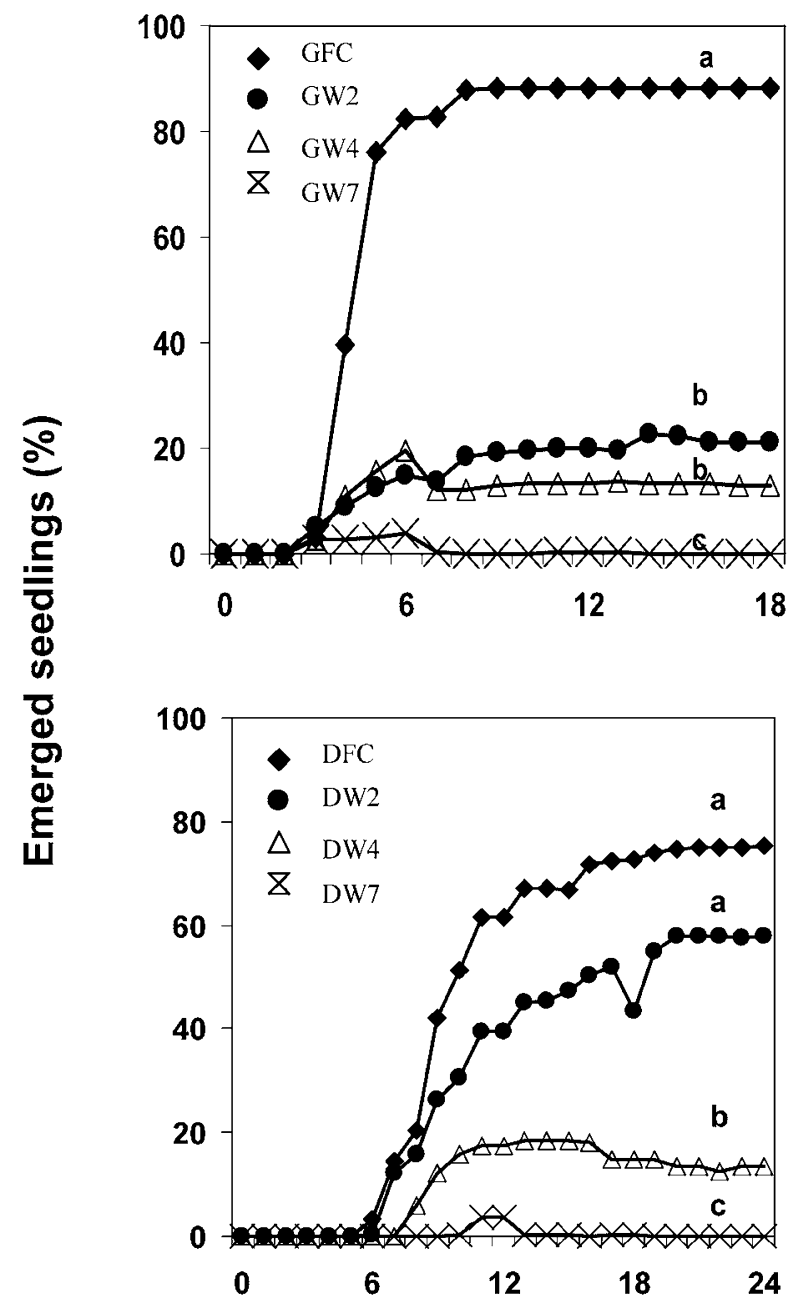

Time (days since sowing)

Figure 3. Seedlings emergence as percent of sown seeds of Dallisgrass as a percent of pregerminated and dry (not treated) sown seed and under 4 irrigation frequencies: Field capacity (FC), or irrigated every 2 (W2), 4 (W4), or 7 days (W7). Different letters indicate significant differences $(P \leq 0.05)$

$(P<0.0001)$ by continuous water availability compared to the other 3 treatments (Fig. 2). Watering every 7 days dramatically decreased seedling emergence of both types of seeds to $6 \%$ and $4 \%$, respectively. Seedling mortality increased as watering frequency decreased (Fig. 2). Seedlings of pregerminated seeds in treatments W2, W4, and W7 died on the second or third day after emerging, as reposition of watering did not permit recovery. All seedlings in treatment W7 died.

Emergence Dynamics. The emergence of seedlings of pregerminated seeds was greatest from the FC treatment. Emergence began 3 days after seeding (Fig. 3 ) and was complete after 5 days. The emergence index for this treatment was significantly highest (Table 2). Initial emergence was delayed as watering frequency decreased (up to 8 and 10 days after seeding). Treatment R7 showed the lowest emergence index. No emergence was detected when watering was provided after the experiment (Fig. 3).
Table 2. Seedling emergence index of pregerminated and sown seeds affected by different watering frequencies: kept continually at field capacity. (FC) and irrigated every 2 (W2), 4 (W4), or 7 days (W7). Different letters indicate significant differences $(P \leq 0.05)$ according to Scheffe's Test.

\begin{tabular}{ccc}
\hline Treatment & $\begin{array}{c}\text { Pregerminated } \\
\text { seeds }\end{array}$ & $\begin{array}{c}\text { Dried (not treated) } \\
\text { seeds }\end{array}$ \\
\hline FC & $30.3 \mathrm{a}$ & $16.4 \mathrm{~b}$ \\
W2 & $10.6 \mathrm{bc}$ & $11.2 \mathrm{bc}$ \\
W4 & $7.1 \mathrm{~cd}$ & $4.3 \mathrm{~cd}$ \\
W7 & $2.5 \mathrm{~cd}$ & $0.7 \mathrm{~d}$ \\
\hline
\end{tabular}

The emergence of seedlings from dried seeds occurred 7 days after seeding and spread over more than 20 days, especially in treatments FC and W2 (Fig. 3). Seedling emergence in treatment W4 only occurred after the third watering (ie, $>12$ days). A small emergence peak in treatment W7 was observed after the second watering. With the exception of FC treatment, the emergence index showed no significant difference between dry seeds and pregerminated ones (Table 2).

Time period from emergence to second-leaf appearance was significantly shorter for pregerminated seeds in treatment FC than for those in treatment W4. This interval increased as soil water availability decreased (Table 3). No differences between watering regimes were found in seedling development from dry seeds, although those have demonstrated differences in speed of emergence (Table 2).

Following the 28-day test period when the experiment finished, all pots were rewatered and maintained at field capacity. No additional emergence was recorded in pots seeded with pregerminated seeds, indicating death of all germinant seeds that had not emerged earlier. In contrast, additional seedling emergence occurred in pots seeded with dry seeds, $27.2 \%(\mathrm{SE}= \pm 24.27 \%)$ in W4 (in 5 pots) and $31.91 \%$ $(\mathrm{SE}= \pm 10.45 \%)$ in W7 (in all pots).

Seedling Morphology and Allometry. Seedlings emerging from pregerminated seeds (Tables 2 and 3) were larger than those originating from dry seeds (Table 4$)(P<0.05)$. The analysis of the seedlings originated from pregerminated seeds at 15 days showed that those of treatment FC had $2.9( \pm 0.07)$ leaves expanded and the greatest aboveground and total biomass. Water availability also increased biomass and length and branching of seminal and adventitious roots. Seedlings of treatment W2 showed low root development, while seminal roots of seedlings irrigated every 4 days showed little or no branching and no adventitious roots. Length of these roots was

Table 3. Days from seeding up to emergence of the second leaf in Dallisgrass pregerminated and dry (not treated) seeds. See watering treatments in Table 2. Different letters indicate significant differences $(P \leq 0.05)$.

\begin{tabular}{lcc}
\hline & $\begin{array}{c}\text { Pregerminated } \\
\text { seeds }\end{array}$ & $\begin{array}{c}\text { Dried (not treated) } \\
\text { seeds (d) }\end{array}$ \\
\hline FC & $3.85 \mathrm{a}$ & $6.90 \mathrm{ab}$ \\
W2 & $4.48 \mathrm{bc}$ & $6.48 \mathrm{a}$ \\
W4 & $5.85 \mathrm{ab}$ & $6.63 \mathrm{a}$ \\
\hline
\end{tabular}


Table 4. Effect of different watering frequencies: kept continually at field capacity (FC), irrigated every 2 (W2), and 4 days (W4) over morphological and allometrical characters of Dallisgrass seedlings (at 15 days emergence) from pregerminated and dry (not treated) sowed seed. The values shown are mean and standard error (between brackets). Different letters indicate significant differences $(P \leq 0.05)$ for each variable and each type of sown seed, according to Scheffe's test.

\begin{tabular}{|c|c|c|c|c|c|c|}
\hline \multirow{2}{*}{$\begin{array}{l}\text { Sown seed } \\
\text { Treatment variable }\end{array}$} & \multicolumn{3}{|c|}{ Pre-germinated } & \multicolumn{3}{|c|}{ Dry (not treated) } \\
\hline & $\mathrm{FC}$ & W2 & W4 & FC & W2 & W4 \\
\hline Shoot height (mm) & $31.80( \pm 0.86) \mathrm{a}$ & $26.77( \pm 1.54) b$ & $19.40( \pm 1.42) \mathrm{C}$ & $23.0( \pm 1.09) x y$ & $25.27( \pm 1.56) x$ & $21.15( \pm 0.92) \mathrm{y}$ \\
\hline Number of leaves & $2.90( \pm 0.07) \mathrm{a}$ & $2.83( \pm 0.09) \mathrm{a}$ & $2.26( \pm 0.12) b$ & $2.55( \pm 0.12) x$ & $2.72( \pm 0.11) x$ & $2.00( \pm 0.11) y$ \\
\hline Seminal root length (mm) & $128.05( \pm 7.20) \mathrm{a}$ & $114.83( \pm 6.39) a b$ & $105.40( \pm 7.12) b$ & $123.78( \pm 4.52) x$ & $137.78( \pm 5.86) \times$ & $128.38( \pm 4.28) x$ \\
\hline Adventitious root length (mm) & $79.15( \pm 7.25) \mathrm{a}$ & $68.89( \pm 9.48) a$ & $32.40( \pm 9.48) b$ & $45.83( \pm 7.18) x$ & $44.44( \pm 7.54) x$ & $19.46( \pm 6.38) y$ \\
\hline Shoot biomass (mg) & $3.66( \pm 0.19) \mathrm{a}$ & $2.44( \pm 0.23) b$ & $2.05( \pm 0.24) b$ & $1.68( \pm 0.12) x$ & $1.79( \pm 0.12) x$ & $1.51( \pm 0.13) x$ \\
\hline Root biomass (mg) & $7.28( \pm 0.85) \mathrm{a}$ & $5.79( \pm 0.67) \mathrm{a}$ & $5.17( \pm 0.61) a$ & $4.17( \pm 0.28) y$ & $6.52( \pm 0.58) x$ & $4.59( \pm 0.39) \mathrm{y}$ \\
\hline Total biomass (mg) & $10.94( \pm 0.92) \mathrm{a}$ & $8.23( \pm 0.81) b$ & $7.22( \pm 0.70) b$ & $5.85( \pm 0.35)$ y & $8.31( \pm 0.66) x$ & $6.11( \pm 0.45) y$ \\
\hline Root biomass/shoot biomass & $2.00( \pm 0.20) b$ & $2.51( \pm 0.26) a b$ & $2.85( \pm 0.41) \mathrm{a}$ & $2.63( \pm 0.21) y$ & $3.70( \pm 0.29) x$ & $3.18( \pm 0.30) x y$ \\
\hline Root length/shoot height & $4.10( \pm 0.29) b$ & $4.50( \pm 0.32) \mathrm{ab}$ & $5.59( \pm 0.38) a$ & $5.59( \pm 0.32) x$ & $5.75( \pm 0.36) x$ & $6.18( \pm 0.29) x$ \\
\hline
\end{tabular}

$50 \%$ less than those of treatment W2. The root:shoot ratio increased as soil water availability decreased (Table 4).

No differences in development and biomass accumulation were found in seedlings originating from dry seeds at different watering regimes, although seedlings of treatment FC emerged more rapidly (Table 2). Root biomass and branching were higher in treatment W2. Seedlings in treatment W4 accumulated the same biomass as treatment FC, but its seminal root was shortest and adventitious roots developed slowly. The root:shoot ratio was greater for $\mathrm{W} 2$ and $\mathrm{W} 4$ than for the FC treatment.

\section{DISCUSSION}

Dallisgrass was particularly susceptible to water stress during the seed-germination period. As water stress increased, total germination decreased and emergence was delayed. It is known that the optimal germination occurs in soils at field capacity (Hunter and Erickson 1952; McGinnies 1960; Sharma 1976; Roundy et al. 1985). However, the threshold water potential value under which germination is not possible varies with species (Hunter and Erickson 1952; Briede and McKell 1992). We found that Dallisgrass germination decreased quickly below $-0.5 \mathrm{MPa}$. Species of semiarid grasslands can germinate at -2 $\mathrm{MPa}$ (eg, Agropyron elongatus and Elymus cinereus) (Roundy et al. 1985) and at $-1.5 \mathrm{MPa}$ (Danthonia caespitosa and Atriplex nummularia) (Sharma 1976). Similar results were found by Mullahey et al. (1996) in 2 cultivars of Paspalum notatum: germination decreased with increasing water stress, but the threshold value at which germination occurred was more negative $(-0.75 \mathrm{MPa})$ than the one we found. This will condition the germination of this species to high and consistent water availability. Delay of germination is associated with high susceptibility of seedlings to competition for resources (Harper 1977).

We found that seedling emergence in the greenhouse decreased as the watering interval and water stress increased. Furthermore, planting dry seeds delayed germination and seedling emergence because germination processes were initiated in the soil and dependent on water availability. For this, the germination rate was even more reduced than for pregerminated seeds. These had the advantage of rapid and uniform emergence. But mortality previous to seedling emergence (when germination was incipient) was high. Loss of viability in seeds at an advanced stage of germination is usually attributed to cellular damage in growing root tissue caused by dehydration (Hegarty 1978). Frasier et al. (1984, 1985) also found a high mortality rate for seedlings of Bouteloua curtipendula and Panicum antidotale subjected to dehydration soon after germination.

Seedling survival of various grass species is related to daily cycles of soil watering and drying as a consequence of a high evaporative demand for soil in periods of high air temperatures (Frasier et al. 1987). In our greenhouse experiment, dry seeds that produced no seedlings retained viability and germinated when watering was resumed. However, pregerminated seeds did not. Hauser (1986) found that Paspalum notatum had $<5 \%$ emergence of both pregerminated and dry seeds but produced seedlings from $97 \%$ of the untreated live seeds after frequent watering.

Holt (1956) reported that Dallisgrass presence was promoted in rice fields of Texas. Presoaking seeds increased seed germination in seed sources of Dallisgrass coming from lowland sites of flooding pampas of Argentina (Blanco et al. 1995; Schrauf et al. 1995a, 1995b). Cornaglia (2002) found that winter flooding promoted seedling emergence, mainly during spring.

Seedling establishment strongly depends on root development in soil, an aspect positively associated with soil temperature and humidity (Briske and Wilson 1978; Hsu et al. 1985). Briske and Wilson (1978) showed that, when the Bouteloua gracilis seminal root is growing in moist deeper soil, seedlings can initiate adventitious roots even during severe drought conditions in surface horizons of the soil. This would explain why Dallisgrass seedlings in treatment W4 had initiated adventitious roots growth, even later that FC, because the seminal root was growing at a depth where soil water content was higher. Cornaglia (2002) found after exhuming seeds that some had germinated but failed to emerge because of the rapidly drying soil surface during sunny summer days. We conclude that susceptibility to water stress during germination and initial growth of this species is high and that rapid germination and early adventitious root growth occurs only under continuous 
water availability. The situation is further complicated because high temperatures are required to break seed dormancy (Schrauf et al. 1995b). Thus, fulfilment of temperature and water requirements would be very infrequent, explaining the difficulty of establishing Dallisgrass. We conclude that the pattern of soil water availability reduces the temporal frame under which successful establishment of this species would be possible, except in very humid habitats.

\section{ACKNOWLEDGMENTS}

We are grateful to E. Jobbágy, R. Fernández, R. Ansley, and two anonymous reviewers for their valuable comments on earlier drafts.

\section{LITERATURE CITED}

Acosta, G., V. A. Deregibus, and F. Zucchinl. 1994. Inclusión de Pasto Miel (Paspalum dilatatum Poir.) en Pasturas: 1. Efecto sobre la producción forrajera. Revista Argentina de Producción Animal 14:175-185.

Blanco, M. A., G. E. Schrauf, and V. A. Deregibus. 1995. Efecto de las condiciones de incubación y pre-incubación sobre el comportamiento germinativo de poblaciones de Paspalum dilatatum Poir. de la Pampa Deprimida. Ecología Austral 5:140-155.

Brar, G. S., J. L. Steiner, P. W. Unger, and S. S. Prihar. 1992. Modelling sorghum seedling establishment from soil wetness and temperature of drying seed zones. Agronomy Journal 84:905-910.

Briede, J. W., and C. M. McKell. 1992. Germination of seven perennial arid land species, subjected to soil moisture stress. Journal of Arid Environments 23:263-270.

BRISKE, D. D., AND A. M. WILSON. 1978. Moisture and temperature requirements for adventitious root development in bluegrama seedlings. Journal of Range Management 31:174-178.

Burkart, S., R. J. C. León, And C. P. Movia. 1990. Inventario fitosociológico del pastizal de la Depresión del Salado (Prov. de Buenos Aires) en un área representativa de sus principales ambientes. Darwiniana 30:27-69.

Burton, G. W. 1942. Observations of the flowering habits of four Paspalum species. American Journal of Botany 29:179-187.

Cornaglia, P. S. 2002. Paspalum dilatatum: Germinación y establecimiento en pastizales naturales [Magister Scientiae Thesis]. Buenos Aires, Argentina: Universidad de Buenos Aires.

Frasier, G. W., J. R. Cox, and D. A. Woolhiser. 1985. Emergence and seedling survival of seven warm-season grasses for six wet-dry sequences. Journal of Range Management 38:372-377.

Frasier, G. W., J. R. Cox, and D. A. Woolhiser. 1987. Wet-dry cycle effects on warmseason grass seedling establishment. Journal of Range Management 40: 2-6.

Frasier, G. W., D. A. Woolhiser, and J. R. Cox. 1984. Emergence and seedling survival of two warm-season grasses as influenced by timing of precipitation: a greenhouse study. Journal of Range Management 37:7-11.

Greacen, E. L., G. R. Walker, and P. G. Cook. 1989. Procedure for the filter paper method of measuring soil water suction. CSIRO Division of Soils Divisional Report 108:1-7.

GRImoldi, A. A. 2000. Respuestas plásticas a la inundación en especies vegetales de un pastizal de la Pampa Deprimida [Magister Scientiae Thesis]. Buenos Aires, Argentina: Universidad de Buenos Aires.

Hardegree, S. P., and W. E. Emmerich. 1994. Seed germination response to polyethylene glycol solution depth. Seed Science and Technology 22:1-7.

Harper, J. L. 1977. Population biology of plants. London, UK: Academic Press.
Hauser, V. L. 1986. Emergence of several grasses from pregerminated seed and some soil water effects. Agronomy Journal 78:206-210.

Hegarty, T. W. 1978. The physiology of seed hydration and dehydration and the relation between water stress and the control of germination: a Review. Plant, Cell and Environment 1:101-119.

HoLt, E. C. 1956. Dallisgrass. Texas Agricultural Experimental Station Bulletin 829:1-14.

Hsu, F. J., And C. J. Nelson. 1986. Planting date effects on seedlings development of perennial warm-season forage grasses. II. Seedling growth. Agronomy Journal 78:38-42.

Hsu, F. J., C. J. Nelson, and A. G. Matches. 1985. Temperature effects on germination of perennial warm season forage grasses. Crop Science 25:215-220.

Hunter, J. R., AND A. E. ERICKSON. 1952. Relation of seed germination to soil moisture tension. Agronomy Journal 44:107-109.

Hyder, D. N., A. C. Everson, and R. E. Bement. 1971. Seedling morphology and seedling failures with bluegrama. Journal of Range Management 24: 287-292.

Lemcoff, J. H., O. E. Sala, V. A. Deregibus, R. J. C. León, and T. Schlichter. 1978. Preferencia de los vacunos por los distintos componentes de un pastizal de la Depresión del Salado. CIC (Prov de Buenos Aires), Monografías 8:57-70.

LORETI, J., AND M. OESTeRheld. 1996. Intraspecific variation in the resistance to flooding and drought in populations of Paspalum dilatatum from different topographic positions. Oecologia 108:279-284.

Loreti, J., M. Oesterheld, and R. J. C. León. 1994. Efectos del pastoreo y la inundación sobre Paspalum dilatatum, un pasto nativo de la Pampa Deprimida. Ecología Austral 4:49-58.

MAGUIRE, J. D. 1962. Speed of germination-aid in selection and evaluation for seedling emergence and vigor. Crop Science 2:176-177.

McGinNies, W. J. 1960. Effects of moisture stress and temperature on germination of six range grasses. Agronomy Journal 52:159-162.

Mullahey, J. J., S. H. West, and J. A. CoRnell. 1996. Effects of simulated drought by polyethylene glycol on bahiagrass germination. Seed Science and Technology 24:219-224.

Owen, C. R. 1951. Improvement of native Dallisgrass (Paspalum dilatatum) in Louisiana. Louisiana Agricultural Experimental Station Bulletin 449.

Parmar, M. T., and R. P. Moore. 1966. Effect of simulated drought by polyethylene glycol solutions on corn (Zea maiz I.) germination and seedling development. Agronomy Journal 58:391-392.

Rossi, J. L., V. A. Deregibus, and F. González. 1998. Efecto de la cobertura del suelo y del pretratamiento de las semillas sobre el establecimiento de Pasto miel (Paspalum dilatatum Poir.), sembrado en primavera. Actas del $22^{\circ}$ Congreso Argentino de Producción Animal 18:150-151.

Roundy, B. A., J. A. Young, and R. A. Evans. 1985. Germination of basin wildrye and tall wheatgrass in relation to osmotic and matric potential. Agronomy Journal 77:129-135.

Rubio, G., G. Casasola, and R. S. Lavado. 1995. Adaptations and biomass production of two grasses in response to waterlogging and soil nutrient enrichment. Oecologia 102:102-105.

Schrauf, G. E., P. S. Cornaglia, V. A. Deregibus, and M. G. Ríssola. 1995a Improvement in germination behaviour of Paspalum dilatatum Poir. seeds under different pre-conditioning treatments. New Zealand Journal of Agricultural Research 38:501-509.

Schrauf, G. E., M. A. Blanco, and V. A. Deregibus. 1995b. Germination behaviour of Paspalum dilatatum under simulated condition of grazing and flooding. Proceeding Fifth International Rangeland Congress. Salt Lake City, Utah. $1: 494-495$.

Sharma, M. L. 1976. Interaction of water potential and temperature effects on germination of three semi-arid plant species. Agronomy Journal 65:982-987. 